\title{
DIEL VARIATION IN ABUNDANCE AND SIZE OF THE SOUTH AMERICAN RED SHRIMP PLEOTICUS MUELLERI (SPENCE BATE, 1888) (DECAPODA, SOLENOCERIDAE) IN THE UBATUBA REGION, SOUTHEASTERN BRAZIL
}

\author{
Mateus Lopes ${ }^{1,2,3, *}$, Adilson Fransozo ${ }^{2}$, Antonio Leão Castilho ${ }^{2}$ and Rogerio Caetano da Costa ${ }^{1}$ \\ ${ }^{1}$ Universidade Estadual Paulista "Julio de Mesquita Filho" (UNESP) \\ Faculdade de Ciências, Departamento de Ciências Biológicas, UNESP, Campus de Bauru \\ Laboratório de Biologia de Camarões Marinhos e de Água Doce \\ (Av. Eng. Luiz Edmundo Carrijo Coube, 14-01, 17033-360 Bauru, SP, Brasil) \\ ${ }^{2}$ Universidade Estadual Paulista "Julio de Mesquita Filho" (UNESP) \\ Instituto de Biociências, Departamento de Zoologia, UNESP, Campus de Botucatu \\ (Distrito de Rubião Júnior, S/N, 18618-970 Botucatu, SP, Brasil) \\ ${ }^{3}$ Universidade de São Paulo (USP) \\ Faculdade de Filosofia, Ciências e Letras de Ribeirão Preto (FFCLRP) - Departamento de Biologia, \\ Laboratório de Bioecologia e Sistemática de Crustáceos \\ (Av. Bandeirantes, 3900; 14040-901 Ribeirão Preto, SP, Brasil) \\ *Corresponding author: lopesm4383@gmail.com
}

http://dx.doi.org/10.1590/S1679-87592014067806203

\begin{abstract}
A B S T R A C T
Diel variation in the abundance and size of Pleoticus muelleri in the Ubatuba region was investigated during 2000. During each season of the year, sampling was conducted during the day and at night at 8 depths, from 5 to $40 \mathrm{~m}$. The estimated number of shrimp was 955 individuals, 272 collected during the day and 683 at night. There was a difference in the abundance of $P$. muelleri between day and night $\left(\chi^{2}, \mathrm{p}=2.33 \mathrm{E}-40\right)$. The abundance during the day and at night differed by season with the exception of the spring $\left(\chi^{2}, \mathrm{p}=0.06\right)$. The abundance during both periods also differed by depth, except at 15 and $30 \mathrm{~m}$, where it was not significant $\left(\chi^{2}, \mathrm{p}=0.84\right.$ and 0.06 , respectively). The shrimp caught at night were generally smaller than those caught during the day (Kolmogorov-Smirnov, $\mathrm{p}<0.01$ ). Pleoticus muelleri juveniles were found primarily at night. This tendency could have influenced the lower mean size for this period. The sediment type and the bottom temperature appear to influence the behavior of this species and consequently the catch rate during the periods analyzed.
\end{abstract}

\section{RES UMO}

A variação diuturna na abundância e no tamanho de Pleoticus muelleri foi investigada na região de Ubatuba durante o ano de 2000. Em cada estação do ano, as coletas foram realizadas no período diurno e noturno em 8 profundidades, de 5 a $40 \mathrm{~m}$. O número estimado de camarões foi de 955 indivíduos, 272 coletados durante o dia e 683 à noite. Houve diferença na abundância de $P$. muelleri entre o dia e a noite $\left(\chi^{2}, \mathrm{p}=2.33 \mathrm{E}-40\right)$. A abundância durante o dia e à noite diferiu por estação com exceção da primavera $\left(\chi^{2}, \mathrm{p}=0.06\right)$. A abundância em ambos os períodos também diferiu por profundidade, exceto nos 15 e 30 metros $\left(\chi^{2}, p=0.84\right.$ e 0.06 , respectivamente). Os camarões capturados à noite foram geralmente menores do que os capturados durante o dia (Kolmogorov-Smirnov, $\mathrm{p}<0.01$ ). Os juvenis de Pleoticus muelleri foram encontrados principalmente à noite e tal tendência pode ter influenciado no menor tamanho médio obtido nesse período. O tipo de sedimento e a temperatura de fundo parecem influenciar o comportamento da espécie em questão e, consequentemente, a taxa de captura durante os períodos analisados.

Descriptors: Dendrobranchiata, Shrimp fisheries, Catch rate, Diurnal, Nocturnal, South Atlantic. Descritores: Dendrobranchiata, Pesca camaroneira, Taxa de captura, Diurno, Noturno, Atlântico Sul. 


\section{INTRODUCTION}

Pleoticus muelleri, commonly known as "Santana"" or red shrimp, is restricted in its geographical distribution to the southwestern Atlantic. The species occurs from Rio de Janeiro $\left(23^{\circ} \mathrm{S}\right.$, Brazil) to Santa Cruz $\left(50^{\circ} \mathrm{S}\right.$, Argentina). Its life cycle is exclusively marine. Higher biomasses are found in salinities above 30 and at temperatures below $20^{\circ} \mathrm{C}$ (COSTA et al., 2004; MALLO, 2005; CASTILHO et al., 2008a).

Of the Penaeoidea, the red shrimp ranks 6th among the commercially exploited species harvested by the fishing fleet in the state of São Paulo. However, its proportion in catches has been increasing in recent years due to an increase in the size and fishing power of the fleet and decreases in the stocks of the principal target species, i.e., the pink shrimp (Farfantepenaeus brasiliensis (Latreille, 1817) and Farfantepenaeus paulensis (Pérez-Farfante, 1967)), the white shrimp (Litopenaeus schmitti (Burkenroad, 1936)) and the seabob shrimp (Xiphopenaeus kroyeri (Heller, 1862)) (D'INCAO et al., 2002; CASTILHO et al., 2007a).

Most of the available information on $P$. muelleri concerns populations in Argentinian waters (BOSCHI; ANGELESCU, 1962; BOSCHI; MISTAKIDIS, 1966; MALLO; CERVELLINI, 1988; BOSCHI, 1989; IORIO et al., 1996; BOSCHI, 1997; BERTUCHE et al., 2000; DÍAZ et al., 2003; MALLO, 2005). Information on the biology of this species has also been obtained from the southeastern coast of Brazil, specifically from the state of São Paulo, including reports on the species' ecological distribution (COSTA et al., 2004), its reproductive biology (CASTILHO et al., 2008a) and the relationship between environmental variation and species abundance in the shrimp community (CASTILHO et al., 2008b). However, no studies on the variation between day and night in the catch and size of the South American red shrimp have yet been undertaken in any part of the area of its geographical distribution. Studies of this type will provide assistance for the formulation of proposals regarding appropriate management plans and will also assist in the establishment of a fishing season that is more suitable than the present one for the development of a fishery for this species in the region.

Dall et al. (1990) suggested that most penaeid shrimp remain burrowed in the substratum during the day and emerge at night. This behavior provides protection against predators and also allows for a lower energy expenditure because the shrimp decrease their metabolic rate when burrowed (LAKSHMI et al., 1976; VANCE, 1992; CLARK et al., 2003). Laboratory experiments have indicated that at least certain species of Penaeidae are much more active at night and are thus more vulnerable to capture by nets (PONTES; ARRUDA, 2005; PONTES, 2006). According to Moctezuma and Blake (1981) and Simões et al. (2010), the juveniles remain not burrowed for a longer period than do the adults because their food requirements are higher as a result of their high growth rate.

According to Dall et al. (1990), penaeid shrimp clearly respond to light by burrowing during the day and emerging at night, and they also clearly respond to factors that affect light intensity. The three major factors considered to influence light intensity and, thus, shrimp behavior are diel changes (continuous light and continuous darkness, clear days, cloudy days, and storms), moonlight and turbidity. In relation to turbidity, Penn (1984) noted that the type of sediment can affect burrowing behavior. In locations with silt and clay sediments, the turbidity of the water may be higher, and the catch does not differ between periods. In contrast, the turbidity in sandy locations is lower, and the shrimp are more abundant at night in these locations.

The present study aimed to analyze the diel variation in abundance and size of individuals of $P$. muelleri caught to a depth of $40 \mathrm{~m}$ in the Ubatuba region on the northern coast of the state of São Paulo. The study sought to determine whether the catch of this species is greater at night, as proposed in the literature. In addition, the capture of the juvenile and adult phases and of males and females during the day and at night was also analyzed. The present study also provided information on the periods associated with abundances of juveniles. Accordingly, the results of this study can serve as a framework for the definition and implementation of management plans that encourage sustainable fishing.

\section{Material and Methods}

The Ubatuba region is located along the northern coastline of the state of São Paulo and is an important area for crustacean investigations and for fisheries. This region, a unique area of the Brazilian southeastern coast, comprises a system of inlets, bays, canals, bayous and rivers bordered by mangroves. Together, these features constitute nutrient-rich estuaries that favor the establishment and development of marine fauna (MANTELATTO; FRANSOZO, 1999). The mixed feature of the fauna of this region can be explained by the thermal regime of the waters, which can 
harbor tropical, temperate and subantartic species (COELHO; RAMOS, 1972; COSTA et al., 2000).

According to Castro-Filho et al. (1987), the Ubatuba region is strongly influenced by three water masses: South Atlantic Central Water (SACW), Tropical Water (TW), and Coastal Water (CW). These water masses interact to modify the temperature, salinity and nutritional characteristics of the habitat during the seasons, especially during the winter and summer.

The sampling for this study was performed in Ubatuba Bay (Fig. 1). This relatively pristine area has been used as a standard for comparison with other marine habitats that are strongly influenced by humans (MANTELATTO; FRANSOZO, 1999; CASTRO et al., 2005). Samples were collected seasonally in March (summer), May (autumn), August (winter) and November (spring) 2000 during the day and at night. The samples were collected during the day, between 07:00 and 17:00 h, and at night, between 19:00 and 05:00 h. The sampling was always performed at flood tide. However, light intensity and lunar brightness were not measured, and tidal cycles, lunar phases and local variations of cloud coverage were not taken into consideration. For each sample, shrimp were collected with the aid of a fishing boat equipped with double-rig nets (mesh size $20 \mathrm{~mm}, 18 \mathrm{~mm}$ at the cod end) trawled for 30 minutes over a distance of approximately $2 \mathrm{~km}$ (approximate area: 18,000 $\mathrm{m}^{2}$ ) at depths of 5, 10, $15,20,25,30,35$ and $40 \mathrm{~m}$. An ecobathymeter coupled with a GPS device was used to record the depth (m) at the sampling sites.

The total wet weight (in grams) of the $P$. muelleri caught in each trawl was determined. When the weight of the sample unit exceeded $250 \mathrm{~g}$, a random subsample (250 g) was taken, and the number of individuals was counted for each depth in each season. The total number of individuals of the sample unit for each depth, season, and period was estimated based on the data from the subsample and from the total biomass.

The carapace length (CL) of each individual was measured to the nearest $0.1 \mathrm{~mm}$ from the orbital angle to the posterior margin of the carapace. The shrimp were sexed according to the presence (in males) and absence (in females) of the petasma (CASTILHO et al., 2008a). Size-frequency distributions were constructed separately for each sex with $2.0 \mathrm{~mm}$ CL size intervals to investigate seasonal variations in size structure and any possible differences in the size of individuals between the daytime and night samples and between the sampled depths (CASTILHO et al., 2007b).

Juveniles and adults were distinguished based on Bauer and Rivera-Vega (1992). Females were considered adult if they were as large as or larger than the smallest female bearing mature ovaries $(11.1 \mathrm{~mm})$. Similarly, males were considered adult if they were as large as or larger than the smallest male with a fused petasma (9.1 $\mathrm{mm})$.

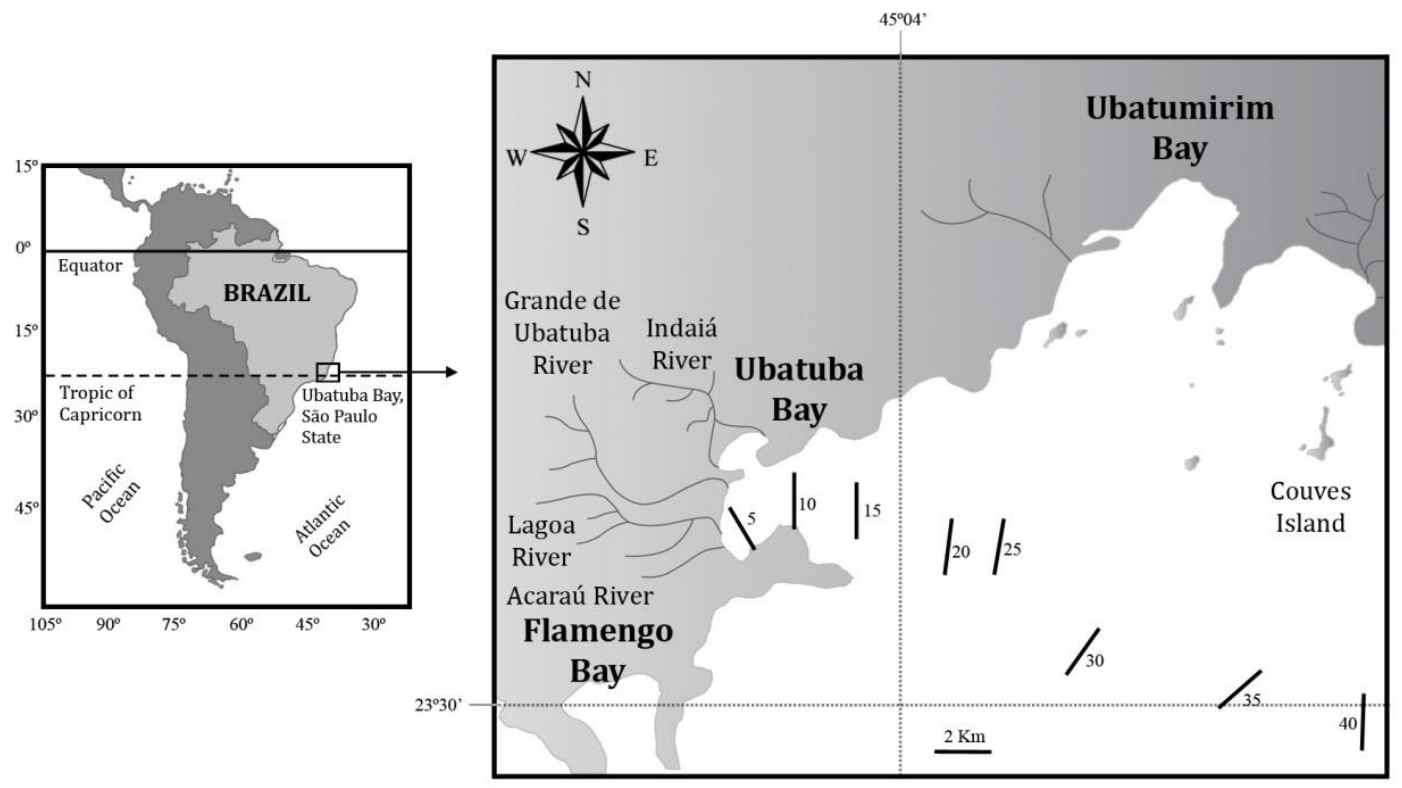

Fig. 1. Map of the Ubatuba region showing the water depths where sampling occurred. 
Data on the bottom water salinity and temperature, surface water temperature, sediment grain size and content of organic matter were recorded for each sample once at each depth. A detailed description of the sampling methods and an analysis of the environmental parameters during the study period are available in Bertini et al. (2001). A Nansen bottle was used to sample the bottom and surface water. The salinity was measured with an Atago S/ ${ }_{1000}$ hand-held optical refractometer, and the temperature $\left({ }^{\circ} \mathrm{C}\right)$ was measured using a thermometer attached to the bottle.

Sediment was sampled at each depth with a Van Veen grab $\left(0.06 \mathrm{~m}^{2}\right)$. The sediment samples were dried, in the laboratory, at $70^{\circ} \mathrm{C}$ for $72 \mathrm{~h}$. For the analysis of the grain-size composition, two $50 \mathrm{~g}$ subsamples were treated with $250 \mathrm{~mL}$ of a $0.2 \mathrm{~N}$ $\mathrm{NaOH}$ solution, stirred for 5 minutes to release silt and clay particles, and then rinsed on a $0.063 \mathrm{~mm}$ sieve. The grain-size categories followed the American standard. According to this standard, the sediment samples were sieved at $2.0 \mathrm{~mm}$ (gravel), $1.0 \mathrm{~mm}$ (very coarse sand), $0.5 \mathrm{~mm}$ (coarse sand), $0.25 \mathrm{~mm}$ (intermediate sand), $0.125 \mathrm{~mm}$ (fine sand) and $0.0625 \mathrm{~mm}$ (very fine sand), and smaller particles were classified as silt-clay. Then, the mean values obtained from both subsamples were calculated for each of the grain-size categories mentioned above. In addition, fractions were expressed on the phi $(\phi)$ scale with the formula $\phi=$ $\log _{2}$ grain diameter (mm) (TUCKER, 1988), i.e., 1 $=\phi<0$ (very coarse sand), $0=\phi<1$ (coarse sand), $1=\phi<2$ (intermediate sand), $2=\phi<3$ (fine sand), $3=\phi<4$ (very fine sand) and $\phi \geq 4$ (silt + clay). The mean particle size (Md $\phi)$ was calculated with the formula $\mathrm{Md}=\left(\phi_{16}+\phi_{50}+\phi_{84}\right) / 3$, in which $\phi_{16}$, $\phi_{50}$ and $\phi_{84}$ correspond to the $16^{\text {th }}, 50^{\text {th }}$ and $84^{\text {th }}$ percentiles, respectively.

The organic matter content (\%) was obtained by ash-weighing. Three aliquots of $10 \mathrm{~g}$ each per depth were placed in porcelain crucibles, incinerated at $500^{\circ} \mathrm{C}$ for $3 \mathrm{~h}$, and then weighed again. The final value for each depth was calculated as the mean of the three values.

Data were examined for normality using visual inspections as well as by conducting a Kolmogorov-Smirnov test. Where necessary, data were transformed using the Box-Cox power transformation in order to select the most adequate procedure (SOKAL; ROHLF, 1995). Nonparametric tests were applied for statistical analysis because all attempts to obtain a normal distribution were unsuccessful. The differences in the abundance of individuals between day and night samples and comparisons among seasons and depths were examined using a Chi-square test (SOKAL; ROHLF, 1995). This non-parametric approach was most appropriate because of the between-sample dependence of data (ZAR, 1999). Finally, a Kolmogorov-Smirnov test was conducted to analyze possible differences in the frequency distribution of the carapace size between the periods (SOKAL; ROHLF, 1995). All data analyses were conducted with Statistica 7.0 (Statsoft Inc.) with a significance level of $\alpha=5 \%$.

\section{Results}

The highest mean $( \pm$ s.d.) value of bottom salinity occurred during the winter $(35.4 \pm 3.0)$, and the lowest mean occurred during the spring $(33.8 \pm 1.9)$. Moreover, the lowest mean ( \pm s.d.) salinity values occurred in shallower waters $(5 \mathrm{~m}=$ $33.0 \pm 2.5$ and $10 \mathrm{~m}=33.7 \pm 2.6)$, whereas the highest values were observed at the sampling sites deeper than $30 \mathrm{~m}(35 \mathrm{~m}=35.0 \pm 2.3$ and $40 \mathrm{~m}=35.1 \pm 2.0)$. The salinity increased slightly from the shallows to the deeper sites. The lowest mean salinity for all the sites sampled was recorded at the 5 and $10 \mathrm{~m}$ depths near the river mouth. The highest salinities were recorded during the autumn and winter, and the lowest salinities were recorded during the summer and spring (Table 1 and Table 2).

Table 1 . Values (mean \pm standard deviation) of bottom salinity and bottom and surface temperature $\left({ }^{\circ} \mathrm{C}\right.$ ), with minimum (Min) and maximum (Max) value ranges, sampled in the Ubatuba region over different seasons of the year.

\begin{tabular}{cccccccccccc}
\hline & \multicolumn{3}{c}{ Bottom salinity } & \multicolumn{3}{c}{ Bottom temperature $\left({ }^{\circ} \mathbf{C}\right)$} & \multicolumn{2}{c}{ Surface temperature $\left({ }^{\circ} \mathbf{C}\right)$} \\
Seasons & & $\mathbf{X} \pm \mathbf{s d}$ & Min & Max & $\mathbf{X} \pm \mathbf{s d}$ & Min & Max & $\mathbf{X} \pm \mathbf{s d}$ & Min & Max \\
\hline Summer & $34.0 \pm 1.0$ & 32.0 & 35.3 & $20.6 \pm 3.1$ & 16.7 & 27.7 & $26.6 \pm 1.0$ & 24.5 & 28.8 \\
Autumn & $35.2 \pm 1.2$ & 33.3 & 37.0 & $21.5 \pm 1.8$ & 19.0 & 25.5 & $24.3 \pm 1.3$ & 22.5 & 26.0 \\
Winter & $35.4 \pm 3.0$ & 30.0 & 38.0 & $19.3 \pm 0.7$ & 18.0 & 20.5 & $19.9 \pm 0.7$ & 18.5 & 21.5 \\
Spring & $33.8 \pm 1.9$ & 31.0 & 38.0 & $20.8 \pm 2.2$ & 17.5 & 25.5 & $23.3 \pm 1.4$ & 21.5 & 26.0 \\
\hline
\end{tabular}


Table 2. Values (mean \pm standard deviation) of bottom salinity and bottom and surface temperature $\left({ }^{\circ} \mathrm{C}\right)$, with minimum and maximum value ranges by depth, and values of sediment diameter (phi) and organic matter (\% O.M.) at each depth in each sampled region during the sampling period.

\begin{tabular}{|c|c|c|c|c|c|c|c|c|c|c|c|}
\hline \multirow{2}{*}{ Depths } & \multicolumn{3}{|c|}{ Bottom salinity } & \multicolumn{3}{|c|}{ Bottom temperature } & \multicolumn{3}{|c|}{ Surface temperature } & \multirow{2}{*}{$\begin{array}{c}\text { Phi } \\
\mathrm{X} \pm \text { sd }\end{array}$} & \multirow{2}{*}{$\begin{array}{c}\% \text { O.M. } \\
\mathrm{X} \pm \mathrm{sd}\end{array}$} \\
\hline & $\mathrm{X} \pm \mathrm{sd}$ & Min & Max & $\mathrm{X} \pm \mathrm{sd}$ & Min & Max & $\mathrm{X} \pm \mathrm{sd}$ & Min & Max & & \\
\hline $5 \mathrm{~m}$ & $33.0 \pm 2.5$ & 31.0 & 38.0 & $23.1 \pm 2.8$ & 19.0 & 27.7 & $24.0 \pm 3.2$ & 19.5 & 28.8 & $5.5 \pm 0.5$ & $4.8 \pm 0.2$ \\
\hline $10 \mathrm{~m}$ & $33.7 \pm 2.6$ & 31.7 & 38.0 & $22.0 \pm 2.3$ & 19.3 & 25.5 & $23.8 \pm 3.1$ & 19.0 & 27.7 & $5.3 \pm 0.7$ & $5.8 \pm 0.2$ \\
\hline $15 \mathrm{~m}$ & $34.5 \pm 2.1$ & 31.0 & 38.0 & $21.2 \pm 2.5$ & 18.7 & 25.7 & $23.6 \pm 2.8$ & 19.5 & 27.5 & $4.5 \pm 0.9$ & $3.6 \pm 0.6$ \\
\hline $20 \mathrm{~m}$ & $34.5 \pm 2.2$ & 30.0 & 38.0 & $20.2 \pm 1.5$ & 18.0 & 23.5 & $23.3 \pm 2.7$ & 19.5 & 27.0 & $3.0 \pm 1.2$ & $1.2 \pm 0.4$ \\
\hline $25 \mathrm{~m}$ & $34.4 \pm 1.9$ & 31.0 & 38.0 & $20.1 \pm 1.5$ & 18.0 & 23.0 & $23.6 \pm 2.6$ & 19.0 & 27.5 & $3.2 \pm 0.7$ & $5.2 \pm 4.0$ \\
\hline $30 \mathrm{~m}$ & $34.6 \pm 1.7$ & 30.3 & 40.0 & $19.4 \pm 1.2$ & 18.0 & 21.7 & $23.6 \pm 2.7$ & 19.2 & 27.0 & $3.0 \pm 0.1$ & $2.1 \pm 0.2$ \\
\hline $35 \mathrm{~m}$ & $35.0 \pm 2.3$ & 31.0 & 38.0 & $19.6 \pm 1.3$ & 18.0 & 22.0 & $23.2 \pm 2.6$ & 19.0 & 28.0 & $2.2 \pm 1.3$ & $3.0 \pm 0.1$ \\
\hline $40 \mathrm{~m}$ & $35.1 \pm 2.0$ & 31.0 & 38.0 & $19.0 \pm 1.2$ & 16.7 & 21.0 & $23.8 \pm 2.9$ & 18.5 & 26.7 & $3.7 \pm 0.8$ & $3.3 \pm 1.1$ \\
\hline
\end{tabular}

The highest mean ( \pm s.d.) bottom temperature $\left(21.5 \pm 1.8^{\circ} \mathrm{C}\right)$ was observed during the autumn, and the lowest $\left(19.3 \pm 0.7^{\circ} \mathrm{C}\right)$ occurred during the winter. The surface water temperatures were $19.9 \pm 0.7$ and $26.6 \pm 1.0^{\circ} \mathrm{C}$ during the winter and summer, respectively (Table 1). The lowest absolute value for bottom water temperature $\left(16.7^{\circ} \mathrm{C}\right)$ was registered at a depth of $40 \mathrm{~m}$, whereas the highest $\left(27.7^{\circ} \mathrm{C}\right)$ was observed at a depth of $5 \mathrm{~m}$, both during the summer. The highest absolute surface temperature value $\left(28.8^{\circ} \mathrm{C}\right)$ was also recorded at a depth of $5 \mathrm{~m}$ during the summer, whereas the lowest value $\left(18.5^{\circ} \mathrm{C}\right)$ was observed at a depth of $40 \mathrm{~m}$ during the winter (Tables 1 and 2).

The bottom and surface temperatures showed a marked difference. The bottom temperatures were always lower, especially during the summer. The lowest mean temperatures and the smallest differences between the surface and the bottom were recorded during the winter (Table 1). The bottom temperatures decreased gradually with depth over the sampling sites (Table 2).

The mean sediment particle size (phi) ranged from $0.07(35 \mathrm{~m})$ to $6.18(10 \mathrm{~m})$. At depths of 5 to $15 \mathrm{~m}$, silt and clay predominated. Higher proportions of sand were recorded at the other depths. Very fine sand predominated at depths of $20,25,30$, and $40 \mathrm{~m}$. Fine sand predominated at 35 $\mathrm{m}$ (Table 2). The percentage of organic matter ranged from $0.85(20 \mathrm{~m})$ to $8.83(25 \mathrm{~m})$, and the highest organic matter content was recorded in shallower waters $(5$ and $10 \mathrm{~m})$. At greater depths, especially at depths of 20 and $30 \mathrm{~m}$, the organic matter content was slightly lower than that recorded in the bay. In general, the phi values were directly related to the amount of organic matter and inversely related to depth (Table 2).

Non-parametric tests were applied because all attempts to obtain a normal distribution were unsuccessful (Abundance data: KolmogorovSmirnov, $\mathrm{d}=0.22413, \mathrm{p}<0.01$; Carapace size data: Kolmogorov-Smirnov, $\mathrm{d}=0.07356, \mathrm{p}<0.01)$. A total of $955 P$. muelleri were caught in the area of Ubatuba. Of these specimens, 272 (105 males and 167 females) were collected during the daytime and 683 (179 males and 504 females) were collected at night. The total number of individuals collected was significantly higher at night $\left(\chi^{2}=88.4, \mathrm{df}=1\right.$, $\mathrm{p}=2.33 \mathrm{E}-40$ ).

Comparisons for each season were performed, and the results subsequently faced. Significant differences were found for summer $\left(\chi^{2}=73.3, \mathrm{df}=1, \mathrm{p}=9.22 \mathrm{E}-34\right)$, autumn $\left(\chi^{2}=15.6\right.$, $\mathrm{df}=1, \mathrm{p}=2.35 \mathrm{E}-08)$ and winter $\left(\chi^{2}=18.7, \mathrm{df}=1\right.$, $\mathrm{p}=9.80 \mathrm{E}-10$ ); For spring, the number of shrimps sampled at night was higher than during the day, however, no statistically significant differences were found $\left(\chi^{2}=1.8, \mathrm{df}=1, \mathrm{p}=0.06\right)$. A greater number of shrimp were captured at night during the summer and the autumn. During those seasons, the ratio of the number of individuals collected during the day to the number of those captured at night was approximately 0.2 . This ratio increased to 0.5 during the winter and to 0.769 during the spring. Both of these seasons had higher juvenile proportions in the population (Fig. 2). 


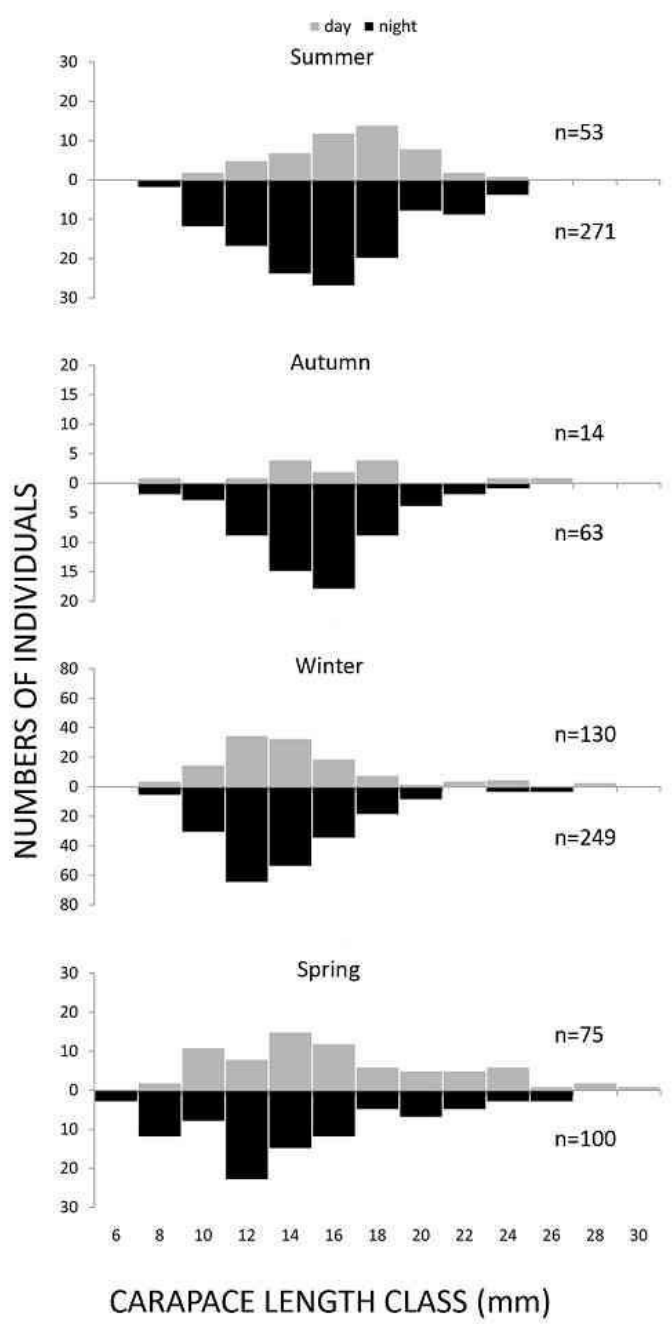

Fig. 2. Number of individuals of Pleoticus muelleri by carapace length class $(\mathrm{mm})$ collected during the day and at night during each season of the year. The $\mathrm{x}$-axis values shown on the graph correspond to the midpoint of each carapace length class.

Pleoticus muelleri was more abundant at depths of 15 to $25 \mathrm{~m}$. In all, $69.2 \%$ of the total number of individuals collected occurred in the samples from these depths. The number of individuals differed significantly at most depths (5 $\mathrm{m}: \chi^{2}=5.6, \mathrm{df}=1, \mathrm{p}=7.89 \mathrm{E}-04 ; 10 \mathrm{~m}: \chi^{2}=5.5, \mathrm{df}=1$, $\mathrm{p}=8.74 \mathrm{E}-04 ; 20 \mathrm{~m}: \chi^{2}=76.4, \mathrm{df}=1, \mathrm{p}=4.33 \mathrm{E}-35 ; 25$ $\mathrm{m}: \chi^{2}=9.8, \mathrm{df}=1, \mathrm{p}=9.77 \mathrm{E}-06 ; 35 \mathrm{~m}: \chi^{2}=16.0, \mathrm{df}=1$, $\left.\mathrm{p}=1.54 \mathrm{E}-08 ; 40 \mathrm{~m}: \chi^{2}=56.0, \mathrm{df}=1, \mathrm{p}=3.57 \mathrm{E}-26\right)$. By contrast, the catches at 15 and $30 \mathrm{~m}$ did not differ significantly $\left(\chi^{2}=0.02, \mathrm{df}=1, \mathrm{p}=0.84\right.$ and $\chi^{2}=1.7$, $\mathrm{df}=1, \mathrm{p}=0.06$, respectively).
Fewer shrimp were observed at the shallower depths, especially at $5 \mathrm{~m}$. At 10 and $15 \mathrm{~m}$, the $P$. muelleri catch rate was higher during the day, whereas below $20 \mathrm{~m}$, the catch rate was higher at night. At a depth of $40 \mathrm{~m}, 112$ specimens were captured. However, 106 of these shrimp were collected in the winter at night. No shrimp were captured at 35 or $40 \mathrm{~m}$ during the day (Fig. 3).

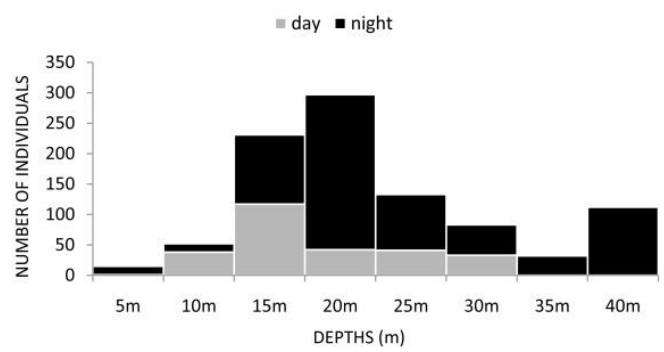

Fig. 3. Number of individuals of Pleoticus muelleri collected during the day and at night at each depth during the sampling period.

The males were less abundant and smaller than the females during all seasons of the year. The highest catch rate of adults and juveniles of both sexes occurred at night during all seasons of the year. The analysis of carapace length showed that the shrimp caught at night were generally smaller than the shrimp caught during the day (Kolmogorov-Smirnov test, $\mathrm{dmax}=0.16, \mathrm{p}<0.01$ ) (Figs 2 and 4).

\section{Discussion}

Diurnal patterns of activity occur in many species of penaeid shrimp (HUGHES, 1968). In general, $P$. muelleri follows the pattern proposed by Dall et al. (1990) for penaeids, i.e., most marine shrimp species remain burrowed-during the day and emerge at night. Diurnal burrowing activity is common in the majority of penaeids (STONER, 1991; VANCE, 1992; BISHOP et al., 2008; SIMÕES et al., 2010).

According to Pontes and Arruda (2005) and Pontes (2006), who studied the behavior and displacement pattern of L. vannamei during light and dark periods, laboratory observations indicated that certain species of Penaeidae are much more active at night and thus more vulnerable to net capture. Hence, the results for P. muelleri obtained by the current study are consistent with those previously observed for members of the Penaeidae because $70 \%$ of the $P$. muelleri individuals were captured at night. However, the studies cited above did not find a specific difference in capture rates related to the type of sediment in the sampling area. 
$\operatorname{MALE}(\mathrm{A})$

$\square$ Juveniles $(\mathrm{d}=0, \mathrm{n}=0)$

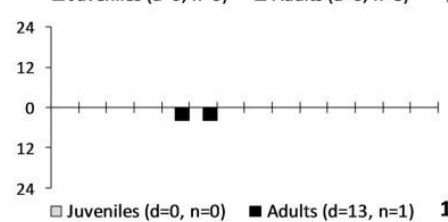

$\square$ Juveniles $(\mathrm{d}=0, \mathrm{n}=0) \quad \boldsymbol{A}$ Adults $(\mathrm{d}=13, \mathrm{n}=1)$

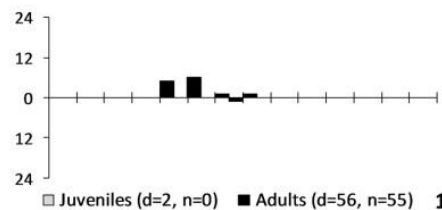

$\square$ Juveniles (d=2, $n=0) \quad$ Adults (d=56, $n=55$ )
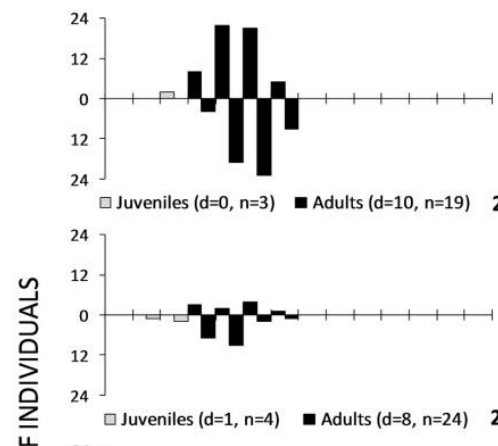

岁 24

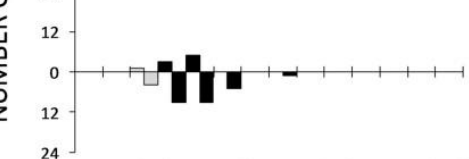

$\square$ Juveniles (d=0, n=4) $\quad$ Adults ( $=13, n=8)$
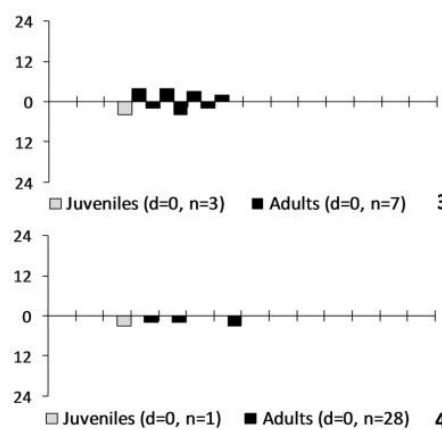

$\square$ Juveniles ( $d=0, n=1$ )

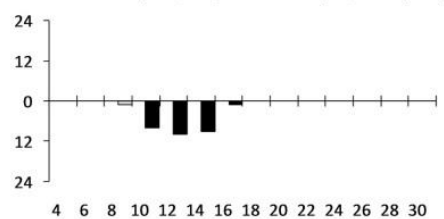

FEMALE (B)

$5 \mathrm{~m} \square$ Juveniles $(\mathrm{d}=0, \mathrm{n}=1) \quad$ Adults $(\mathrm{d}=1, \mathrm{n}=7)$
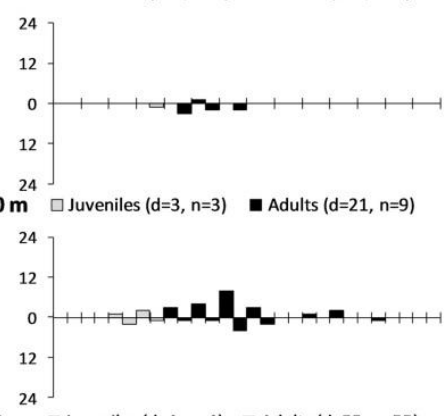

$15 \mathrm{~m} \square$ Juveniles (d=4, $\mathrm{n}=4$ ) $\quad$ Adults $(\mathrm{d}=55, \mathrm{n}=55$ )
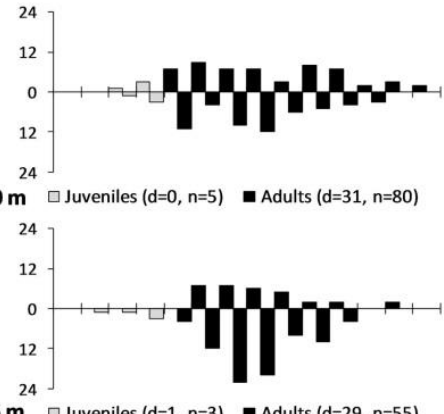

$25 \mathrm{~m} \square$ Juveniles (d=1, $\mathrm{n}=3) \quad$ Adults $(\mathrm{d}=29, \mathrm{n}=55)$
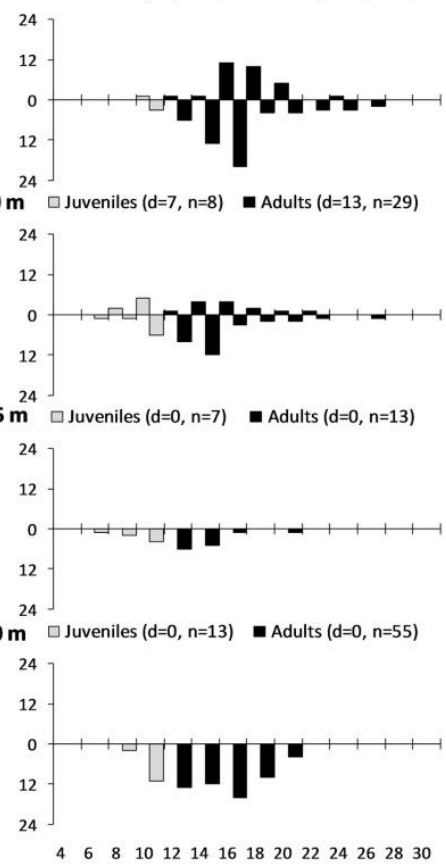

CARAPACE LENGHT CLASS ( $\mathrm{mm}$ )

Fig. 4. Number of juveniles and adults and number of males (A) and females (B), of Pleoticus muelleri by carapace length class (mm), during the day (d) and night (n) for each depth sampled in the study area in 2000. The bars shown above the $\mathrm{x}$ axis corresponds to individuals captured during the day, and the bars below to shrimp captured at night. The $\mathrm{x}$-axis values shown on the graph correspond to the midpoint of each carapace length class. The values of the bars and of the subtitles correspond to the number of individuals measured. 
The results of this study showed that variation in environmental parameters such as the sediment grain size and the temperature can also produce differences in capture rates, thus substantiating the studies performed by Bishop et al. (2008) and Simões et al. (2010). In agreement with the two studies cited above, Boschi (1989) and Costa et al. (2004) observed that sediment type and temperature have been confirmed to exercise great influence on the distribution of P. muelleri.

Penn (1984) developed three models for burrowing behavior based on studies of penaeids caught in the Gulf of Mexico. Type 1 species are strongly nocturnal but are often inactive or burrowed at night. However, they are always burrowed during the day. The species of this type are generally harvested on sandy substrates with relatively clear water. Type 2 species are generally nocturnal and are always active at night. During the day, they are burrowed, but show a tendency to emerge occasionally. They are generally associated with muddier substrates than Type 1 species. The areas with muddier substrates generally have more turbid water. Type 3 species rarely burrow themselves and are almost always active. These species are almost exclusively found in areas of river discharge, which are characterized by high turbidity.

The abundance and spatial distribution of the species studied varied in accordance with the season. The relation between the number of individuals harvested between day and night was not significantly different for spring, however, in all seasons the shrimp were found primarily at night. Moreover, among the sampling sites, only at the depth of $10 \mathrm{~m}$ there was a disparate and highest capture during the day, which occurred only in winter. Whereas on each of the trawls conducted on the eight depths throughout the seasons, the number of shrimp caught was higher during the day on 8 of a total of 32 trawls, no quantitative differences in catch rate were found between day and night in 6 of the 8 . Thus, considering the great disparity between the day and night, it is suggested that $P$. muelleri might be characterized by the Type 2 pattern proposed by Penn (1984).

The results of this study may be linked to the incursion of the South Atlantic Central Water (SACW), especially on the inner shelf during the summer. This incursion causes a decrease in the bottom temperature and salinity at deeper sites. Coupled with the lower temperatures during the winter months, these conditions influenced the increase in the number of individuals of $P$. muelleri, primarily at the depths of 15 and $25 \mathrm{~m}$ (COSTA et al., 2004; CASTILHO et al., 2007b; 2008b). It is probable that the joint effects of the temperature and the types of sediment influenced the stratification of individuals by depth.

Scelzo (2003) verified that the abundance of the post-larvae of Farfantepenaeus notialis (Pérez-Farfante, 1967) and F. brasiliensis (Latreille, 1817) on the Venezuelan coast at night was twice that observed during the day. The collections at night constituted $66.4 \%$ of the total captures. Pontes (2006) investigated the displacement pattern of juvenile shrimp Litopenaeus vannamei (Boone, 1931) submitted to artificial photoperiodic conditions and observed that this displacement occurs primarily during the dark phase. This observation is consistent with the finding that the greatest activity of this species occurs during the dark. Bauer (1985) listed two factors responsible for the increased amounts of certain species of caridean shrimp collected at night. The first factor was the increased activity of the shrimp occurring at night and the resulting exposure to capture by the net. The second factor was the occurrence of nocturnal migrations from deeper regions or from other areas.

Our results clearly demonstrated that the females show a greater tendency to appear in the catches during all seasons of the year. According to Trott (1998) and Castilho et al. (2008c), polygyny is a factor that has been suggested as a probable cause of a deviation from the expected sex ratio (1:1) in penaeoid shrimp. In certain species of the Penaeoidea, a single male may copulate with many females.

Based on 5.5 years of study on the reproduction of $P$. muelleri on the northern coast of the state of São Paulo, Castilho et al. (2008a) indicated that the sex ratio of this species could change in response to migratory events, i.e., the females tend to concentrate in regions or depths other than those where the males concentrate during the reproductive period, primarily when they are ready to spawn. From these observations, it appears probable that the higher number of females observed results from a reproductive strategy of the species.

Díaz et al. (2003) found that Pleoticus muelleri females show a steady increase in size during the breeding season. This size increase can be related to the high energy requirements for reproduction. Furthermore, these authors also found that the females of this species are significantly larger than the males. Their results agree with the results of the current study.

As previously shown by Dall et al. (1990), penaeid juveniles are more active than adults during both day and night. However, unlike the juveniles of other penaeid species described in the literature, the majority of $P$. muelleri juveniles were collected at night in this study. This tendency could have 
influenced the lower mean size for this period. Furthermore, the results of this study suggest that the greatest number of $P$. muelleri adults occurs primarily between depths of 15 and $25 \mathrm{~m}$, where the sediment consists primarily of very fine sand and silt and clay and has a higher content of organic matter. The low capture rates of juveniles during both periods studied, especially in the case of juvenile males, did not allow the identification of a spatial distribution pattern for these individuals.

Our results agreed with the hypotheses suggested in the literature that the capture of $P$. muelleri is more effective during the night and that the type of sediment and the bottom temperature both appear to influence the displacement and the burrowing behavior of the species. The evaluation of the abundance and size of individuals of $P$. muelleri collected throughout the periods analyzed contributed to a better understanding of the life history of the species. However, future studies that include sampling during different lunar phases as well as laboratory experiments to verify the patterns of burrowing behavior during the lunar cycles, with and without light, will contribute to an increased knowledge of the biology of these solenocerids.

\section{ACKNOWLEDGEMENTS}

We are grateful to our NEBECC coworkers for their help during field work. Our thanks are also due to the Fundação de Amparo à Pesquisa do Estado de São Paulo" (FAPESP) for providing financial support (\#97/12106-3, \#97/12107/0 (AF), and \#97/12108-6, 04/07309-8, 09/54672-4, 10/50188-8 (RCC)), to the "Conselho Nacional de Desenvolvimento Científico e Tecnológico" (CNPq) for Research Scholarships (PQ 304784/2011-7 to RCC) and to "Coordenação de Aperfeiçoamento de Pessoal de Nível Superior" (CAPES) for Ongoing Scholarship (PNPD Processo Inicial n ${ }^{\circ}$ 02630/09-5; Atual $\mathrm{n}^{\circ}$ 2823/2013 (ML)). All sampling was conducted in compliance with current applicable state and federal laws in Brazil.

\section{REFERENCES}

BAUER, R. T. Penaeoid shrimp fauna from tropical seagrass meadows: Species composition, diurnal, and seasonal variation in abundance. Proc. Biol. Soc. Wash., v. 98, p. 177-190, 1985.

BAUER, R. T.; RIVERA-VEGA, L. W. Pattern of reproduction and recruitment in two sicyoniid shrimps species (Decapoda: Penaeoidea) from a tropical seagrass habitat. J. Exp. Mar. Biol. Ecol., v. 161, p. 223-240, 1992.

BERTINI, G.; FRANSOZO, A.; COSTA, R. C. Ecological distribution of three species of Persephona
(Brachyura: Leucosiidae) in the Ubatuba region, São Paulo, Brazil. Nauplius, v. 9, p. 31-42, 2001.

BERTUCHE, D.; FISCHBACH, C.; ROUX, A.; FERNÁNDEZ, M.; PIÑERO, R. Langostino (Pleoticus muelleri). En: S. Bezzi, R. Akselman y E. Boschi (eds.), Síntesis del Estado de las Pesquerías Marítimas Argentinas y de la Cuenca del Plata. Años 1997-1998 com uma actualización de 1999. Instituto Nacional de Investigación y Desarollo Pesquero, Mar del Plata, p. 179-190, 2000.

BISHOP, J. M.; YE, Y.; ALSAFFAR, A. H.; ALFOUDARI, H. M.; AL-JAZZAF, S. Diurnal and nocturnal catchability of Kuwait's commercial shrimps. Fish. Res., v. 94, p. 58-72, 2008.

BOSCHI, E. E. Biología pesquera del langostino del litoral patagónico de Argentina (Pleoticus muelleri). Contribuciones INIDEP, v. 646, p. 1-71, 1989.

BOSCHI, E. E. Las pesquerías de crustáceos decápodos en el litoral de la República Argentina. Invest. Mar., Valparaíso, v. 25, p. 19-40, 1997.

BOSCHI, E. E.; ANGELESCU, V. Descripción de la morfología externa e interna del langostino con algunas aplicaciones de índole taxonómica y biológica. Bol. Inst. Biol. Mar., v. 1, p. 1-73, 1962.

BOSCHI, E. E.; MISTAKIDIS, M. Resultados preliminares de las campañas de pesca exploratoria del langostino y el camarón en Rawson. CARPAS Doc. Téc., v. 6, p. 1-15, 1966.

CASTILHO, A. L.; COSTA, R. C.; FRANSOZO, A.; BOSCHI, E. E. Reproductive pattern of the South American endemic shrimp Artemesia longinaris (Decapoda: Penaeoidea), off São Paulo State, Brazil. Rev. Biol. Trop., v. 55, n. 1, p. 39-48, 2007a.

CASTILHO, A. L.; GAVIO, M. A.; COSTA, R. C.; BOSCHI, E. E.; BAUER, R. T.; FRANSOZO, A. Latitudinal variation in population structure and reproductive pattern of the endemic South American shrimp Artemesia longinaris (Decapoda: Penaeoidea). J. Crust. Biol., v. 27, n. 4, p. 548-552, 2007b.

CASTILHO, A. L.; COSTA, R. C.; FRANSOZO, A.; NEGREIROS-FRANSOZO, M. L. Reproduction and recruitment of the South American red shrimp Pleoticus muelleri (Crustacea: Solenoceridae), from the southeastern coast of Brazil. Mar. Biol. Res., v. 4, p. 361-368, 2008a.

CASTILHO, A. L.; PIE, M. R.; FRANSOZO, A.; PINHEIRO, A. P.; COSTA, R. C. The relationship between environmental variation and species abundance in shrimp community (Crustacea: Decapoda: Penaeoidea) in south-eastern Brazil. J. Mar. Biol. Assoc. U.K., v. 88, n. 1, p. 119-123, 2008b.

CASTILHO, A. L.; FURLAN, M.; COSTA, R. C.; FRANSOZO, V. Reproductive biology of the rock shrimp Sicyonia dorsalis (Decapoda: Penaeoidea) from the southeastern coast of Brazil. Invert. Reprod. Develop., v. 52, n. 1-2, p. 59-68, 2008 c.

CASTRO, R. H.; COSTA, R. C.; FRANSOZO, A.; MANTELATTO, F. L. M. Population structure of the seabob shrimp Xiphopenaeus kroyeri (Heller, 1862) (Crustacea: Penaeoidea) on the littoral of São Paulo, Brazil. Sci. Mar., v. 69, n. 1, p. 105-112, 2005.

CASTRO-FILHO, B. M.; MIRANDA, L. B.; MYAO, S. Y. Condições hidrográficas na plataforma continental 
ao largo de Ubatuba: variações sazonais e em média escala. Bol. Inst. Ocean., v. 35, n. 2, p. 135-151, 1987.

CLARK, K. L.; RUIZ, G. M.; HINES, A. H. Diel variation in predator abundance, predation risk and prey distribution in shallow-water estuarine habitats. J. Exp. Mar. Biol. Ecol., v. 287, n. 1, p. 37-55, 2003.

COELHO, P. A.; RAMOS, A. A constituição e a distribuição da fauna de decápodos no litoral leste da América do Sul, entre as latitudes de $5^{\circ} \mathrm{N}$ e 39 $^{\circ}$ S. Trabalhos do Instituto Oceanográfico, Universidade Federal de Pernambuco v. 13, p. 133236, 1972.

COSTA, R. C.; FRANSOZO, A.; MANTELATTO, F. L. M.; CASTRO, R. H. Occurrence of shrimp species (Crustacea: Decapoda: Natantia: Penaeidea and Caridea) in Ubatuba Bay, Ubatuba, SP, Brazil. Proc. Biol. Soc. Wash., v. 113, n. 3, p. 776-781, 2000.

COSTA, R. C.; FRANSOZO, A.; PINHEIRO, A. P. Ecological distribution of the shrimp Pleoticus muelleri (Bate, 1888) (Decapoda: Penaeoidea) in southeastern Brazil. Hydrobiologia, v. 529, p. 195203, 2004.

D'INCAO, F.; VALENTINI, H.; RODRIGUES, L. F. Avaliação da pesca de camarões nas regiões Sudeste e Sul do Brasil. 1965-1999. Atlantica, v. 24, n. 2, p. 103-116, 2002.

DALL, W.; HILL, B. J.; ROTHILSBERG, P. C.; STAPLES, D. J. The biology of the Penaeidae. In: BLAXTER, J. H. S.; SOUTHWARD, A. J. (Ed.). Advances in Marine Biology. San Diego, Academic Press, 1990. v. 27, 489p.

DÍAZ, A. C.; PETRIELLA, A. M.; FENUCCI, J. L. Ciclo de muda y reproducción de la población del langostino Pleoticus muelleri (Crustacea, Penaeoidea) de Mar del Plata. Cienc. Mar., v. 29, n. 3, p. 343-355, 2003.

HUGHES, D. A. Factors controlling the emergence of pink shrimp (Penaeus duorarum) from the substrate. Biol. Bull., v. 134, p. 48-59, 1968.

IORIO, M. I.; MACCHI, G. J.; FISCHBACH, C. E.; CHRISTIANSEN, H. E. Estudios sobre la dinámica reproductiva del langostino Pleoticus muelleri en el área de Bahía Blanca (Provincia de Buenos Aires, República Argentina). Frente marit., v. 16(A), p. 111-118, 1996.

LAKSHMI, G. J., VENKATARAMIAH, A.; GUNTER, G. Effects of salinity and photoperiod on the burying behavior of brown shrimp Penaeus aztecus Ives. Aquaculture, v. 8, n. 4, p. 327-336, 1976.

MALLO, J. C. Ensayo sobre alimentación de postlarvas del langostino argentino (Pleoticus muelleri, Bate) utilizando alimento vivo y diferentes dietas microencapsuladas. Rev. AquaTIC, v. 22, p. 26-38, 2005.

MALLO, J.; CERVELLINI, P. Distribution and abundance of larvae and postlarvae of Artemesia longinaris, Pleoticus muelleri and Peisos petrunkevitchi (Crustacea, Decapoda, Penaeidea) in the coastal waters of the Blanca Bay, Argentina. J. Aqua. Trop., v. 3, p. 1-9, 1988.
MANTELATTO, F. L. M.; FRANSOZO, A. Reproductive biology and moulting cycle of the crab Callinectes ornatus (Decapoda: Portunidae) from the Ubatuba region, São Paulo, Brazil. Crustaceana, v. 72, p. 6376, 1999.

MOCTEZUMA, M. A.; BLAKE, B. F. Burrowing activity in Penaeus vannamei Boone from the CaimaneroHuizache Lagoon system on the Pacific Coast of Mexico. Bull. Mar. Sci., v. 31, n. 2, p. 312-317, 1981.

PENN, J. W. The behavior and catchability of some commercially exploited penaeids and their relationship to stock and recruitment. In: Penaeid Shrimps - The Biology and Management, GULLAND JA AND RPTHSCHIID BJ (Eds), Fishing News Books Limited, Farnham, p. 173-186, 1984.

PONTES, C. S. Padrão de deslocamento do camarão marinho Litopenaeus vannamei (Boone) (Crustacea, Decapoda, Penaeidae) nas fases clara e escura ao longo de 24 horas. Rev. Bras. Zool., v. 23, n. 1, p. 223-227, 2006.

PONTES, C. S.; ARRUDA, M. F. Comportamento de Litopenaeus vannmei (Boone) (Crustacea, Decapoda, Penaeidae) em função da oferta do alimento artificial nas fases clara e escura do período de 24 horas. Rev. Bras. Zool., v. 22, n. 3, p. 648-652, 2005.

SCELZO, M. A. Day and night abundance and density of juvenile pink shrimps Farfantepenaeus notialis (Pérez-farfante) and Farfantepenaeus brasiliensis (Latreille) in La Restinga lagoon, Margarita Island, Venezuela (Decapoda, Penaeidae). Nauplius, v. 1, p. 1-13, 2003.

SIMÕES, S. M.; COSTA, R. C.; FRANSOZO, A.; CASTILHO, A. L. Diel variation in abundance and size of the seabob shrimp Xiphopenaeus kroyeri (Crustacea, Penaeoidea) in the Ubatuba region, southeastern Brazil. An. Acad. Bras. Cienc., v. 82, n. 2, p. 369-378, 2010.

SOKAL, R. R.; ROHLF, F. J. Biometry. W. H. Freeman and Company, New York, 1995. 887p.

STONER, A. W. Diel Variation in the Catch of Fishes and Penaeid Shrimps in a Tropical Estuary. Estuar. Coast. Shelf Sci., v. 33, p. 57-69, 1991.

TROTT, T. J. On the sex ratio of the painted ghost crab Ocypode gaudichaudii H. Milne Edwards \& Lucas, 1843 (Brachyura, Ocypodidae). Crustaceana, v. 71, n. 1, p. 47-56, 1998.

TUCKER, M. Techniques in sedimentology. Boston, US and Oxford, UK: Blackwell Scientific Publications, 1988. 394p.

VANCE, D. J. Activity patterns of juvenile penaeid prawns in response to artificial tidal and day-night cycles: a comparison of three species. Mar. Ecol. Prog. Ser., v. 87, p. 215-226, 1992.

ZAR, J. H. Biostatistical analysis. Prentice Hall, New Jersey, 1999. 663p.

(Manuscript received 07 August 2013; revised 14 June 2014; accepted 15 July 2014) 